\title{
Erratum to: Prices, wages and fertility in pre-industrial England
}

\author{
Marc P. B. Klemp
}

Published online: 7 March 2012

(C) Springer-Verlag 2012

\section{Erratum to: Cliometrica (2012) 6:63-77 \\ DOI 10.1007/s11698-011-0072-5}

Part "g" of Fig. 1 has been published incorrectly in the original version of the article. The correct version of Fig. 1(g) is given below.

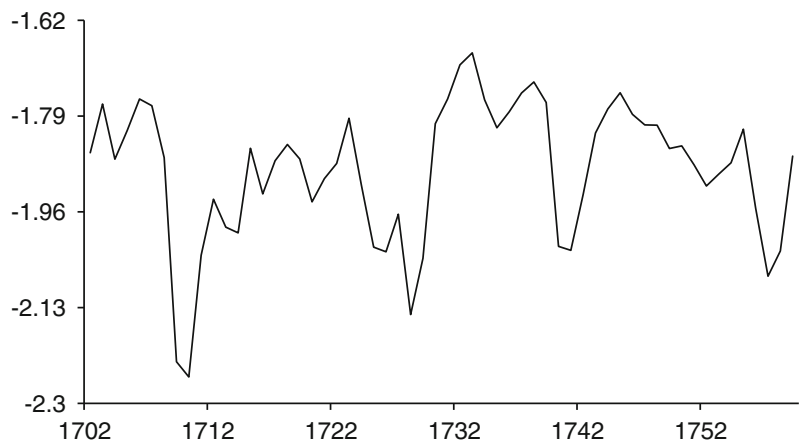

(g) Log of product wages in agriculture

The online version of the original article can be found under doi:10.1007/s11698-011-0072-5.

M. P. B. Klemp (ه)

Department of Economics, University of Copenhagen, Øster Farimagsgade 5,

building 26, 1353 Copenhagen, Denmark

e-mail: Marc.Klemp@econ.ku.dk 